\title{
Improving Normative and Adaptive Teacher Skills in Teaching PKWU Subjects
}

\section{Peningkatan Keterampilan Guru Normatif dan Adaptif dalam Mengampu Mata Pelajaran PKWU}

\author{
Dedi Darwis*, A. Ferico Octaviansyah Pasaribu, \& Sampurna Dadi Riskiono \\ Fakultas Teknik dan Ilmu Komputer, Universitas Teknokrat Indonesia, Jalan ZA Pagar Alam No 9-11, Bandar Lampung, Indonesia
}

\begin{abstract}
Based on the existing guidelines in the 2013 revised curriculum, Creative Products and Entrepreneurship (PKWU) subjects have changed for the number of hours of lessons, namely currently there are six lesson hours for one week, while for adaptive and normative subjects the number of lessons has decreased. However, the teachers at SMK YPI generally do not have dual competencies that can support skills in teaching PKWU subjects. Therefore, training and mentoring are needed as provisions for teachers in teaching PKWU subjects so that the competence and skills of teachers who teach adaptive and normative subjects can increase. The main problem with partners is that the craft program has not been implemented because there is still a need for skills material to be given to students related to entrepreneurship. This service activity is carried out by providing training to normative and adaptive teachers to teach PKWU with materials, namely graphic design and making Bluetooth Mini Amplifier. From the results of the activities carried out, an evaluation was obtained, namely that for an understanding of the PKWU subject, $100 \%$ of his knowledge increased. For the use of graphic design applications and their application after training activities, it shows that $85.71 \%$ of normative and adaptive teachers know how to use graphic design applications and $14.29 \%$ really know and understand the use of graphic design applications. As for the knowledge about making bluetooth mini amplifiers a number of $14.29 \%$ of normative and adaptive teachers know enough and $85.71 \%$ of normative and adaptive teachers know how to make bluetooth mini amplifiers.
\end{abstract}

\begin{abstract}
Abstrak
Berdasarkan pedoman yang ada pada kurikulum revisi 2013, mata pelajaran Produk Kreatif dan Kewirausahaan (PKWU) mengalami perubahan jumlah jam pelajaran, yaitu saat ini ada enam jam pelajaran untuk satu minggu, sedangkan untuk mata pelajaran adaptif dan normatif jumlah pelajarannya telah menurun. Namun guru di SMK YPI umumnya belum memiliki kompetensi ganda yang dapat menunjang keterampilan dalam pembelajaran mata pelajaran PKWU. Oleh karena itu, diperlukan pelatihan dan pendampingan sebagai bekal bagi guru dalam pembelajaran mata pelajaran PKWU agar kompetensi dan keterampilan guru yang mengajar mata pelajaran adaptif dan normatif dapat meningkat. Masalah utama dengan mitra adalah program kriya belum terlaksana karena masih adanya kebutuhan materi keterampilan untuk diberikan kepada mahasiswa terkait kewirausahaan. Kegiatan pengabdian ini dilakukan dengan memberikan pelatihan kepada guru normatif dan adaptif untuk mengajar PKWU dengan materi yaitu desain grafis dan pembuatan Bluetooth Mini Amplifier. Dari hasil kegiatan yang dilakukan didapatkan evaluasi yaitu untuk pemahaman mata pelajaran PKWU 100\% ilmunya meningkat. Untuk penggunaan aplikasi desain grafis dan aplikasinya setelah kegiatan pelatihan menunjukkan bahwa 85,71\% guru normatif dan adaptif mengetahui cara penggunaan aplikasi desain grafis dan 14,29\% benar-benar mengetahui dan memahami penggunaan aplikasi desain grafis. Sedangkan untuk pengetahuan tentang pembuatan amplifier mini bluetooth sejumlah $14,29 \%$ guru normatif dan adaptif cukup tahu dan $85,71 \%$ guru normatif dan adaptif tahu cara membuat amplifier bluetooth mini.
\end{abstract}

(C) 2020 Author(s).

Keywords: Adaptive, Bluetooth Mini Amplifier, Graphic Design, Normative, SMK YPI Tanjung Bintang 


\section{Pendahuluan}

\subsection{Analisis Situasi}

Guru normatif dan adaptif adalah Guru yang mengampu mata pelajaran non kejuruan, Guru normatif biasanya mengampu mata pelajaran seperti : Pendidikan Agama, Pendidikan Kewarganegaraan, Bahasa Indonesia, Penjas dan Seni Budaya. Sedangkan Guru adaptif mengampu mata pelajaran seperti : Matematika, Bahasa Inggris, IPA, IPS, KKPI dan Kewirausahaan (Prasetyo, 2013), (Mardiana \& Sumiyatun, 2017). Berdasarkan panduan yang ada pada kurikulum 2013 revisi, mata pelajaran Produk Kreatif dan Kewirausahaan (PKWU), mengalami perubahan untuk jumlah jam pelajaraanya yaitu saat ini sebanyak enam jam pelajaran selama satu minggu, sedangkan untuk mata pelajaran adaptif dan normatif mengalami penurunan jumlah jam pelajaran (Saputra, Darwis, et al., 2020), (Sulistiani et al., 2020). Hal ini dilakukan sebagai upaya mencetak lulusan SMK yang memiliki keterampilan dalam membuat produk kreatif yang dapat dipasarkan sehingga mampu berwirausaha secara mandiri. Untuk mengganti jumlah jam pelajaran yang menurun untuk adaptif dan normatif, kebijakan pemerintah memperbolehkan Guru yang mengajar pelajaran adaptif dan normatif untuk mengajar matapelajaran PKWU (Anggraini \& Sukardi, 2015), namun para guru pada umumnya belum memiliki kompetensi ganda yang dapat menunjang keterampilan dalam mengampu mata pelajaran PKWU. Maka dari itu diperlukan pelatihan dan pendampingan sebagai bekal kepada para Guru dalam mengampu mata pelajaran PKWU sehingga kompetensi dan keterampilan para Guru yang mengajar mata pelajaran adaptif dan normatif dapat meningkat.

Yayasan Pemuda Indonesia (YPI) Berdiri pada tanggal 14 juli 1998, pada awal berdiri membuka jurusan otomotif dengan jumlah siswa 19 orang, beralamat di Jl. Satria Jatibaru Belakang Kantor Kecamatan Tanjung Bintang Lampung Selatan. Di tahun pelajaran 2019-2020 SMK YPI memiliki 2 jurusan yaitu Teknik Komputer Jaringan (TKJ) dan Teknik Kendaraan Ringan Otomotif (TKRO). SMK YPI Tanjung Bintang berdiri sejak tahun 1998, sekolah ini memiliki tujuan utama yaitu terwujudnya peserta didik yang religius, cerdas, berprestasi, dan mandiri dalam mencetak lulusan yang memiliki bakat dibidang kewirausahaan. Jumlah rombongan Belajar (rombel) 14 Kelas , dengan rincian 5 kelas jurusan TKJ dan 9 Kelas jurusan TKRO. Adapun untuk jumlah ketersediaan Guru pada Sekolah ini adalah 22 Tenaga Pendidik yang terditi dari 10 Guru yang mengampu mata pelajaran produktif dan 12 Guru mengampu mata pelajaran adaptif dan normatif dan dengan dibantu Tenaga Kependidikan sebanyak 7 pegawai (Dapodik, 2020).

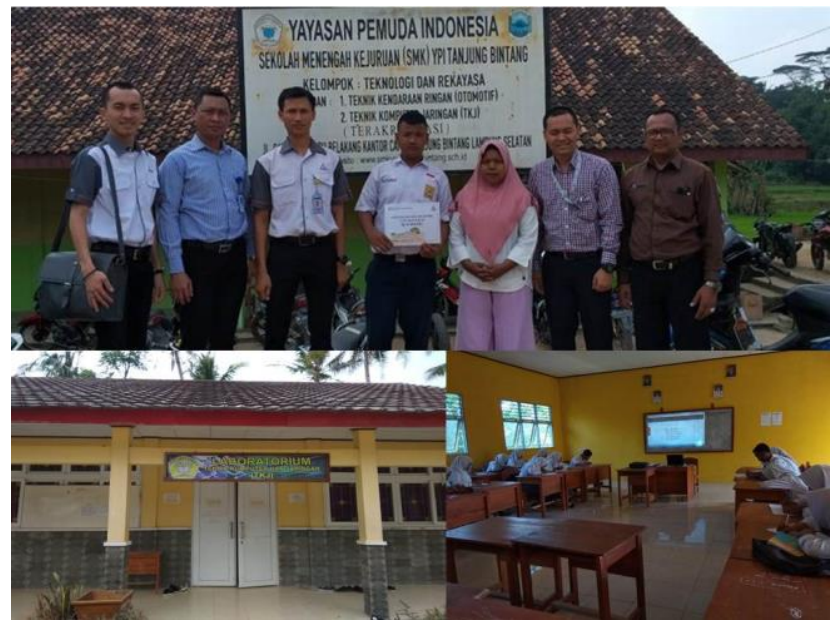

Fig. 1. SMK Yayasan Pemuda Indonesia

\footnotetext{
* Corresponding author:

E-mail address: darwisdedi@teknokrat.ac.id (Dedi Darwis)
} 
Gambar 1 merupakan profil dari SMK Yayasan Pemuda Indonesia, namum SMK ini sudah memiliki beberapa prestasi ditingkat Kabupaten dan Provinsi karena sekolah ini memiliki hasrat untuk selalu meningkatkan kualitas dan prestasi para Siswa dan Guru dengan sumber daya yang masih sangat terbatas. Salah satu prestasi adalah juara lomba robot tingkat Provinsi dan Nasional (Dapodik, 2020).

\subsection{Permasalahan Mitra}

Dalam upaya untuk melaksanakan Kurikulum 2013 yang berkaitan dengan Prakarya yang akan di gunakan sebagai materi Produk Kreatif dan Kewirausahaan (PKWU), maka pihak sekolah berupaya untuk memberikan materi keterampilan. Berkaitan dengan hal tersebut, sebenarnya pihak SMK YPI telah melakukan pengadaan peralatan yang dapat di gunakan sebagai bahan untuk Prakarya. Peralatan yang sudah di sediakan seperti Alat Sabon Kaos, Membuat Desain atau sablon pada Mug, dan Membuat Pin. Peralatan yang sudah disediakan merupakan komitmen pihak sekolah dalam mendukung kompetensi atau kemampuan siswa dalam membuat prakarya sehingga mampu menciptakan peluang usaha bagi para lulusan. Namun demikian masih terdapat beberapa kendala yang dihadapi oleh pihak sekolah.

Permasalahan utama pada mitra adalah : 1) Belum terlaksanya program prakarya karena masih perlu adanya materi keterampilan yang akan di berikan kepada Siswa yang berhubungan dengan Kewirausahaan. Materi yang akan diberikan masih di pertimbangkan karena berkaitan dengan 2 jurusan yang tersedia di SMK YPI yaitu Jurusan Teknik Komputer Jaringan dan Teknik Kendaraan Ringan. 2) Walaupun sudah tersedia beberapa peralatan yang berhubungan dengan percetakan, namun kegiatan tersebut belum terlaksana karena para Guru di SMK YPI belum memiliki keterampilan dalam bidang Digital Printing dan beberapa materi lain yang dibutuhkan untuk menambah pengetahuan tentang Prakarya dan Kewirausahaan.

\subsection{Solusi Permasalahan}

Digital printing, adalah sebuah metode Percetakan dari gambar berbasis digital, yang biasanya berupa file, kemudian bisa langsung dicetak di berbagai media dengan cara yang instan dan cepat (Ulfa \& Saputra, 2019), (Saputra, Pasha, et al., 2020). Digital printing merupakan hasil inovasi perkembangan dari metode percetakan yang konvensional, yang muncul seiring dengan kemajuan teknologi dunia yang sudah masuk di era digital. Umumnya digital printing memiliki biaya produksi yang lebih tinggi untuk per satuannya dibanding metode cetak yang lebih konvensional seperti percetakan offset, sablon / screen printing. Namun, teknik digital printing ini memiliki kelebihan yang tidak dimiliki oleh metode percetakan offset maupun sablon, yaitu tidak memerlukan proses pra cetak seperti pembuatan film, plat cetak (offset), afdruk screen (sablon). Karena proses yang dilalui digital printing lebih ringkas sehingga membuat digital printing menjadi lebih banyak digunakan untuk pengerjaan cetak jumlah skala kecil, mencetak dengan waktu yang sangat cepat dan instan (Maskar, 2018). Ada dua solusi utama yang ditawarkan kepada mitra untuk menyelesaiakan permasalahan yang telah diuraikan yaitu : 1) Mengadakan pelatihan dan pendampingan kepada Guru berkaitan dengan kompetensi Digital Printing. 2) Menawarkan Prakarya dalam bidang Mini Audio Menggunakan Bluetooth receiver.

\section{Metode Pelaksanaan}

\subsection{Tahapan Pelaksanaan}

Metode pelaksanaan yang digunakan dalam kegiatan pengabdian masyarakat ini adalah pelatihan dan pendampingan kepada guru dalam membuat desain untuk kaos, mug, pin dan mini amplifier seperti pada Fig. 2. 


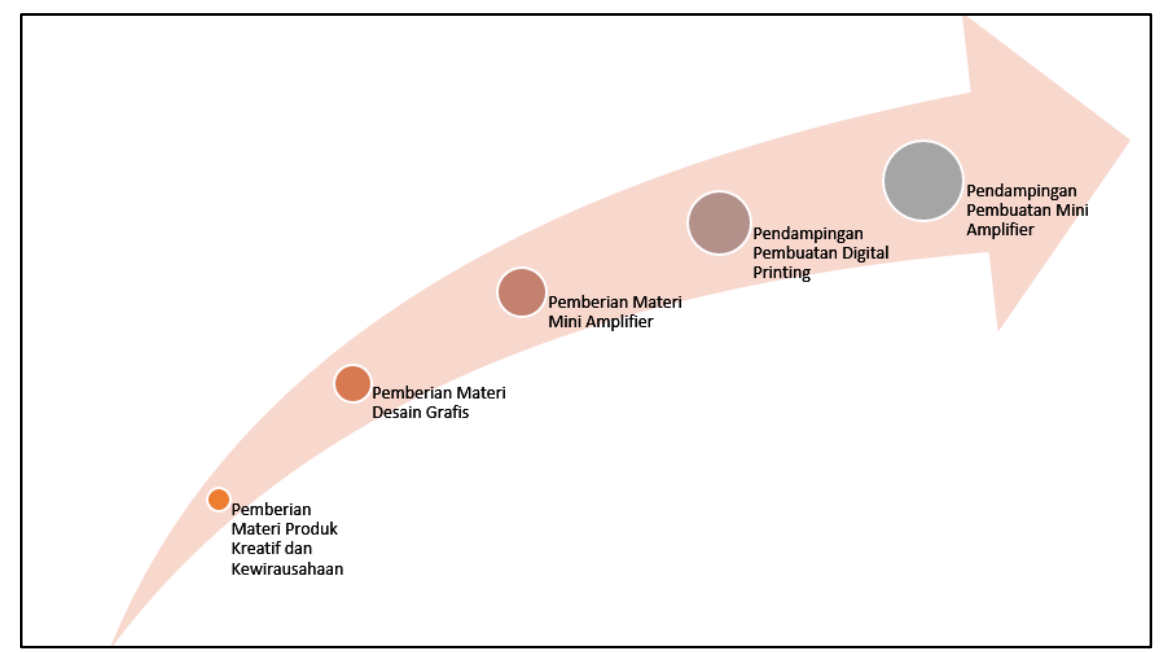

Fig. 2. Tahapan Pelaksanaan Kegiatan

Berikut penjelasan dari tahapan pelaksanaan pada Fig. 2 :

1. Pemberian Materi Produk Kreatif dan Kewirausahaan

Tahapan ini merupakan tahapan awal dalam melaksanakan Pengabdian kepada Masyarakat (PkM). Pada pertemuan ini akan dilakukan penjelasan tentang pemahaman materi yang akan di berikan kepada para Guru. Menjelaskan pokok-pokok materi yang akan menjadi kegiatan pembuatan prakarya sampai dengan peluang bisnis dari prakarya yang dihasilkan.

2. Materi pelatihan keterampilan pertama yang akan diberikan adalah memberikan pelatihan yang berkaitan dengan desain grafis, mulai dari menggunakan aplikasi yang digunakan untuk mendesain sampai praktik cara mencetaknya.

3. Materi berikutnya Membuat Mini Amplifier Bluetooth.

a. Penyampaian Materi Komponen Yang Digunakan

b. Merakit Box Speaker kecil (alat dan bahan)

c. Merakit Komponen Amplifier dan Bluetooth ke dalam box speaker

4. Pendampingan Praktikum Kepada Guru

Kegiatan ini dilakukan untuk melakukan pendampingan atau bimbingan kepada Guru dalam membuat Prakarya Percetakan dalam bidang Digital Printing.

5. Pendampingan Praktikum Kepada Guru

Kegiatan ini dilakukan untuk melakukan pendampingan atau bimbingan kepada Guru dalam membuat Prakarya Mini Amplifier Bluetooth

6. Evaluasi Pemahaman Materi

Pada akhir kegiatan ini akan dilakukan evaluasi untuk mengukur kemampuan para Guru dalam membuat Prakarya sesuai dengan yang sudah di tentukan pada poin 4 dan 5. Jika masih ada Guru yang masih kesulitan atau belum memahami Pembelajaran, maka akan dilakukan pendampingan kembali.

\subsection{Tempat dan waktu Pelaksanaan}

Kegiatan Pengabdian kepada Masyarakat ini dilakukan di SMK YPI Tanjung Bintang, dilaksanakan mulai awal Agustus 2020 sampai dengan akhir Oktober 2020. 


\subsection{Khalayak Sasaran}

Khalayak sasaran pada kegiatan PkM ini yaitu semua guru yang mengampu mata pelajaran yang bersifat normatif dan adaptif di SMK YPI Tanjung Bintang, ada 10 sampai dengan 15 guru yang akan mengikuti kegiatan ini. Setelah para guru pengampu mata pelajaran normatif dan adaptif selesai mengikuti pelatihan ini selanjutnya akan diajarkan ke para siswa SMK YPI Tanjung Bintang yang mengikuti mata pelajaran PKWU.

\section{Hasil dan Pembahasan}

\subsection{Pemberian Materi PKWU}

Kegiatan pertama yang dilakukan pada program PkM ini adalah memberikan pemahaman lebih mendalam untuk guru normatif dan adaptif dalam mengampu mata pelajaran PKWU.

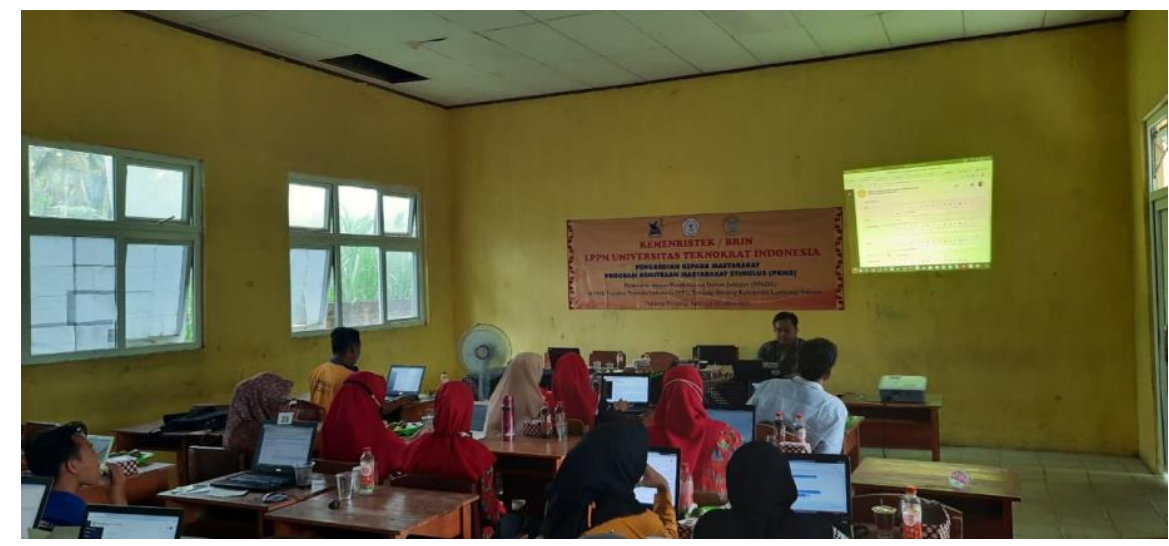

Fig. 3. Kegiatan Pemberian Materi PKWU

Pada Fig. 3 merupakan proses pemberian materi PKWU kepada guru normatif dan adaptif, materi yang disampaikan meliputi :

1) Perancangan silabus PKWU

2) Potensi produk kreatif yang dapat diajarkan kepada siswa

3) Cara memasarkan hasil produk kreatif siswa kepada masyarakat

\subsection{Pelatihan Desain Grafis}

Pada sesi pelatihan desain grafis, para guru normatif dan adaptif diberikan pengetahuan tentang seni dan desain sampai dengan mempraktikkannya menggunakan software komputer seperti pada Fig. 4. Adapun materi yang disampaikan meliputi :

1) Dasar seni desain grafis

2) Desain logo menggunakan CorelDRAW

3) Desain Banner, undangan, pakaian, mug, pin dan cover buku menggunakan Adobe Photoshop

4) Cetak mug dan pin menggunakan peralatan percetakan 


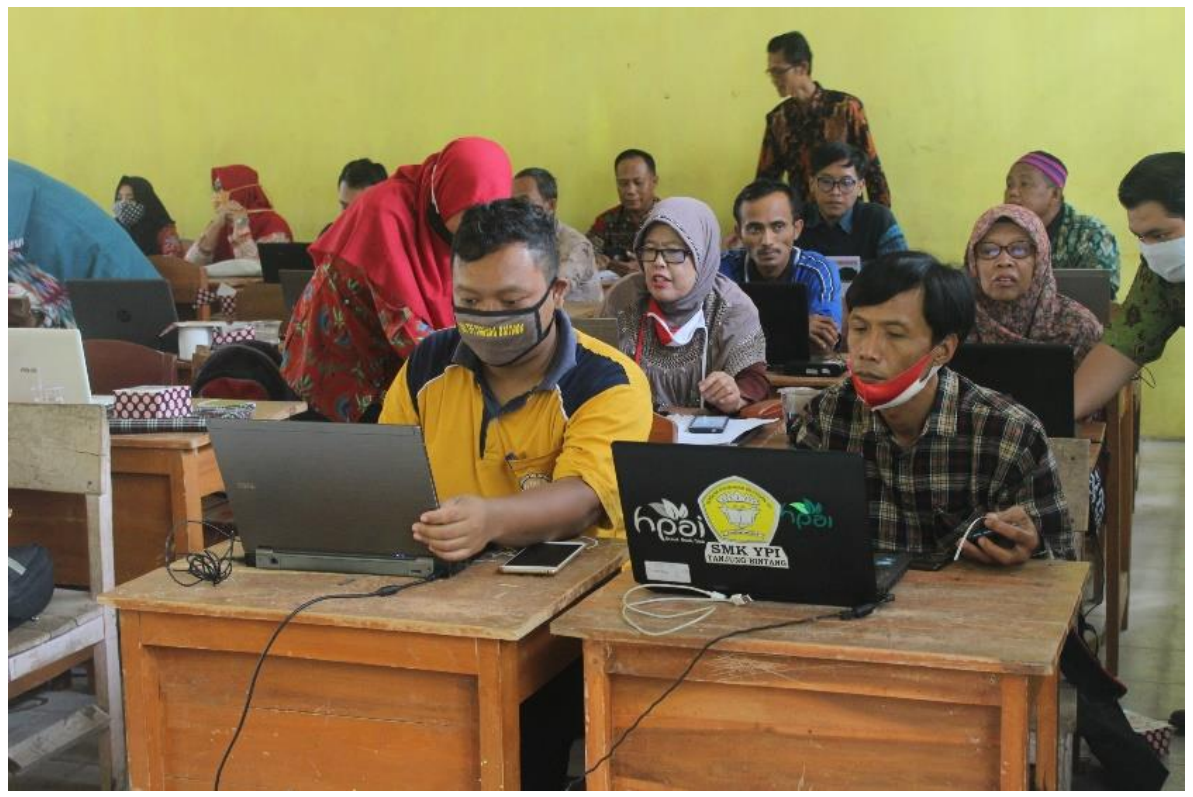

Fig. 4(a). Kegiatan Pelatihan Desain Grafis

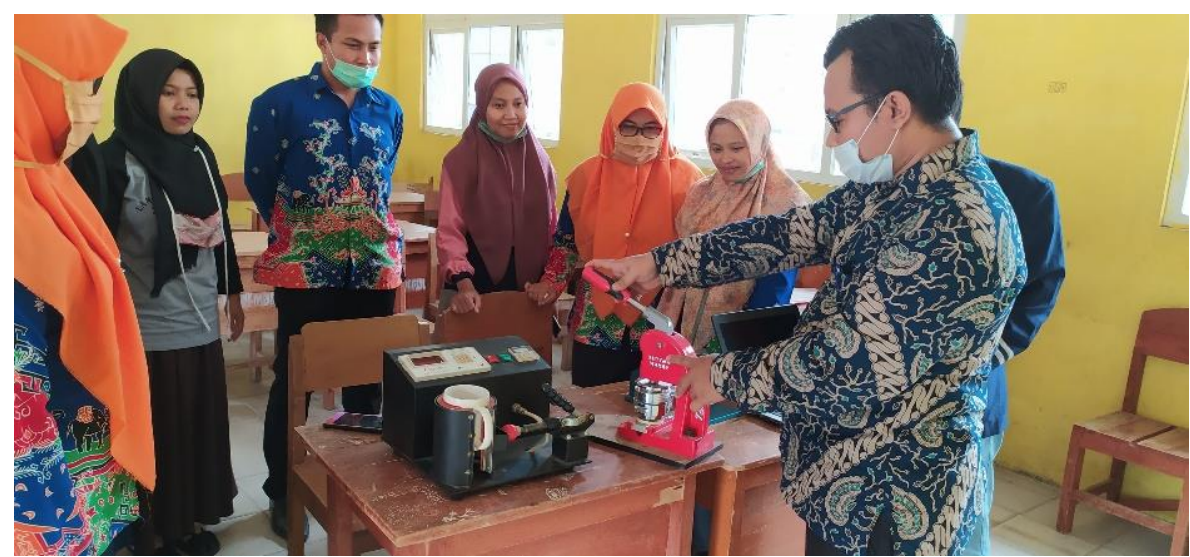

Fig. 4(b). Kegiatan Pelatihan Desain Grafis

\subsection{Pelatihan Membuat Mini Amplifier Bluetooth}

Selain desain grafis, kegiatan lain dalam pelatihan membuat prakarya ini adalah membuat mini amplifier bluetooth dengan Audio yang saat ini banyak digunakan. Bluetooth adalah suatu peralatan media komunikasi yang dapat digunakan untuk menghubungkan sebuah perangkat komunikasi dengan perangkat komunikasi lainnya, bluetooth umumnya digunakan di handphone, komputer atau PC, tablet, dan lain-lain. Fungsi bluetooth yaitu untuk mempermudah berbagi atau sharing file, audio, menggantikan penggunaan kabel dan lain-lain. Saat ini sudah banyak sekali perangkat yang menggunakan bluetooth (Samsugi \& Suwantoro, 2018). Materi yang disampaikan pada pelatihan sesi ini adalah ini :

1) Pendahuluan mengenai materi yang akan di sampaikan
a. Peluang Bisnis 
b. Sasaran Penjualan

2) Penyampaian materi komponen yang digunakan

3) Merakit box speaker kecil (alat dan bahan)

4) Merakit komponen amplifier dan bluetooth ke dalam box speaker

5) Melakukan pendampingan pembuatan mini amplifier bluetooth.

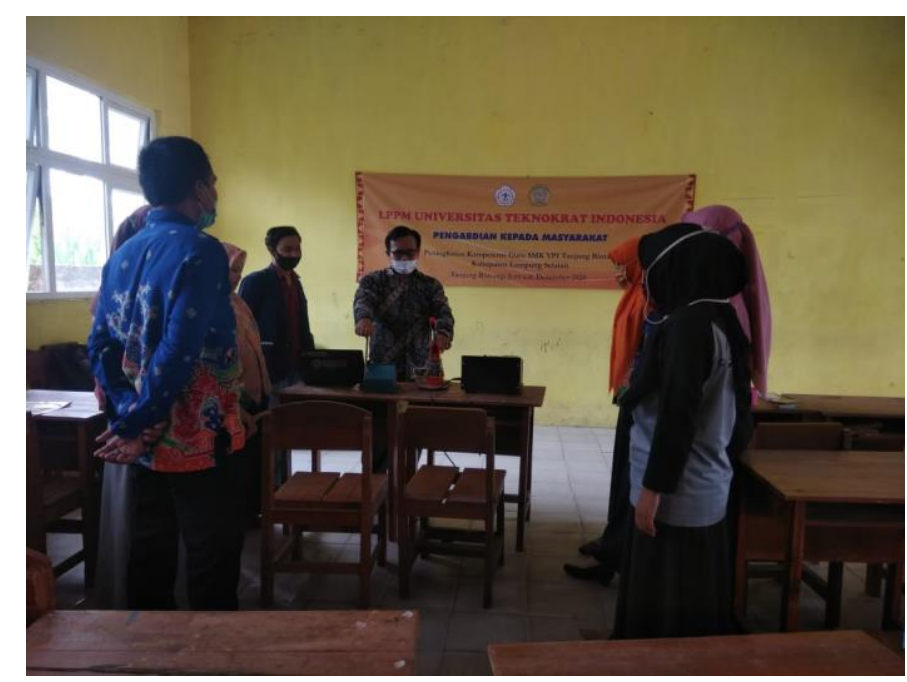

Fig. 5. Kegiatan Pelatihan Pembuatan Mini Amplifier Bluetooth

\subsection{Pendampingan Praktikum Kepada Guru}

Kegiatan ini dilakukan untuk mengawal para guru dalam mengajar mata pelajaran PKWU kepada para siswa SMK YPI Tanjung Bintang. Saat ini, di SMK YPI Tanjung Bintang pada era new normal ini untuk beberapa mata pelajaran praktikum tetap dilaksanakan secara tatap muka dengan persentase siswa hanya 50\% dari tiap kelas, serta mengikuti protokol kesehatan dengan baik. Pada kegiatan pendampingan ini dilakukan secara online/daring via zoom untuk mengevaluasi hasil dari kegiatan pelatihan yang dilakukan. Fig. 6 merupakan kegiatan pendampingan melalui aplikasi via zoom.

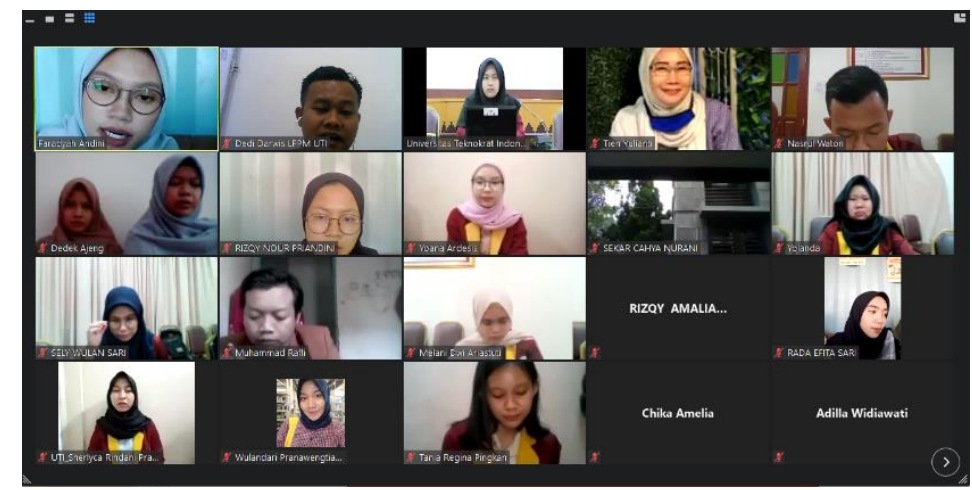

Fig. 6. Kegiatan Pendampingan Via Zoom 


\subsection{Evaluasi Pemahaman Materi}

Untuk mengetahui adanya peningkatan pada pemberdayaan mitra, maka dilakukan evaluasi dengan cara memberikan kuesioner kepada peserta pelatihan sebelum dan sesudah kegiatan dilakukan untuk mengukur pemahaman dan kemampuan para guru pengampu mata pelajaran normatif dan adaptif untuk mengajar mata pelajaran PKWU. Responden pelatihan atau peserta pelatihan sebanyak 14 peserta yang terdiri dari 8 guru normatif dan 6 guru adaptif Adapun hasil evaluasi kegiatan pengabdian yang dilakukan di SMK YPI Tanjung Bintang untuk guru normatif dan adaptif dapat dilihat pada Tabel 1 .

Tabel 1. Peningkatan Keterampilan Guru Normatif dan Adaptif SMK YPI Tanjung Bintang

\begin{tabular}{|c|c|c|c|}
\hline No & Indikator & Sebelum Pelatihan & Sesudah Pelatihan \\
\hline 1 & $\begin{array}{l}\text { Pengetahuan tentang mata pelajaran } \\
\text { PKWU }\end{array}$ & $\begin{array}{l}\text { Tidak Mengetahui }=0 \% \\
\text { Cukup Mengetahui }=35,71 \% \\
\text { Mengetahui }=64,29 \% \\
\text { Sangat Mengetahui }=0 \%\end{array}$ & $\begin{array}{l}\text { Tidak Mengetahui }=0 \% \\
\text { Cukup Mengetahui }=0 \% \\
\text { Mengetahui }=0 \% \\
\text { Sangat Mengetahui }=100 \%\end{array}$ \\
\hline 2 & $\begin{array}{l}\text { Pengetahuan tentang penggunaan } \\
\text { aplikasi desain grafis }\end{array}$ & $\begin{array}{l}\text { Tidak Mengetahui }=85,71 \% \\
\text { Cukup Mengetahui }=14,29 \% \\
\text { Mengetahui }=0 \% \\
\text { Sangat Mengetahui }=0 \%\end{array}$ & $\begin{array}{l}\text { Tidak Mengetahui }=0 \% \\
\text { Cukup Mengetahui }=0 \% \\
\text { Mengetahui }=85,71 \% \\
\text { Sangat Mengetahui }=14,29 \%\end{array}$ \\
\hline 3 & $\begin{array}{l}\text { Pengetahuan tentang membuat Mini } \\
\text { Amplifier Bluetooth }\end{array}$ & $\begin{array}{l}\text { Tidak Mengetahui }=100 \% \\
\text { Cukup Mengetahui }=0 \% \\
\text { Mengetahui }=0 \% \\
\text { Sangat Mengetahui }=\%\end{array}$ & $\begin{array}{l}\text { Tidak Mengetahui }=0 \% \\
\text { Cukup Mengetahui }=14,29 \% \\
\text { Mengetahui }=85,71 \% \\
\text { Sangat Mengetahui }=0 \%\end{array}$ \\
\hline
\end{tabular}

Dari hasil yang disajikan pada Tabel 1 menunjukkan bahwa hasil kegiatan PkM pada SMK YPI Tanjung Bintang, dalam hal peningkatan komptensi bagi guru normatif dan adaptif untuk pemahaman tentang mata pelajaran PKWU $100 \%$ pengetahuannya meningkat. Untuk penggunaan aplikasi desain grafis dan penerapannya setelah dilakukan kegiatan pelatihan menunjukkan bahwa 85,71\% guru normatif dan adaptif mengetahui cara pengunaan aplikasi desain grafis dan 14,29\% sangat mengetahui dan memahami penggunaan aplikasi desain grafis. Sedangkan untuk pengetahuan tentang membuat mini amplifier bluetooth sejumlah $14,29 \%$ guru normatif dan adaftif cukup mengetahui dan $85,71 \%$ guru normatif dan adaptif mengetahui cara membuat mini amplifier bluetooth.

Berdasarkan hasil evaluasi yang dilakukan setelah kegiatan pelatihan dan pendampingan dilakukan, maka guru pengampu mata pelajaran normatif dan adaptif sudah mampu dalam mengajar PKWU dengan memberikan beberapa keterampilan kepada murid, sehingga para murid di SMK YPI Tanjung Bintang dapat mengembangkan hasil produk tersebut menjadi potensi kewirausahaan yang merupakan tujuan utama dari mata pelajaran PKWU.

\section{Kesimpulan}

Berdasarkan hasil pembahasan, dapat disimpulkan bahwa guru normatif dan adaptif di SMK YPI Tanjung Bintang sudah memiliki kemampuan dasar dalam mengampu mata pelajaran PKWU untuk komptensi yang berhubungan dengan desain grafis dan produk hasil desain grafis, serta mengajarkan membuat mini amplifier bluetooth. Kompetensi yang telah dimiliki dapat dijadikan sebagai dasar dalam mengampu mata pelajaran PKWU bagi guru normatif dan adaptif.

\section{Acknowledgements}

Kami tim pelaksana kegiatan Pengabdian kepada Masyarakat mengucapkan terimakasih kepada Universitas Teknokrat Indonesia melalui LPPM yang telah memberikan hibah PkM pada tahun 2020 dengan Nomor Kontrak : 004/UTI/LPPM/E.1.2/VII/2020. 


\section{References}

Anggraini, A., \& Sukardi, S. (2015). Pengembangan Modul Prakarya Dan Kewirausahaan Materi Pengolahan Berbasis Product Oriented Bagi Peserta Didik Smk. Jurnal Pendidikan Vokasi, 5(3), 287. https://doi.org/10.21831/jpv.v5i3.6484

Dapodik. (2020). Data Pokok Pendidikan SMK YPI Tanjung Bintang. http://dapo.dikdasmen.kemdikbud.go.id/sekolah/DD2C39CB9A98B894BCD6

Mardiana, S., \& Sumiyatun. (2017). Implementasi Kurikulum 2013 Dalam Pembelajaran Sejarah. Jurnal Historia, $5(1), 45-54$.

Maskar, S. (2018). Alternatif Penyusunan Materi Ekspresi Aljabar Untuk Siswa Smp/Mts Dengan Pendekatan Pendidikan. Prisma, VII(1), 53-69.

Prasetyo, S. B. (2013). Korelasi Antara Prestasi Mata Pelajaran Normatif, Adaptif Dan Produktif Dengan Pemahaman Karakter Akademik Siswa Program Keahlian Teknik Pemesinan Smkn 2 Kebumen Tahun 2012/2013. Jurnal Telematika, 9(1).

Samsugi, S., \& Suwantoro, A. (2018). Pemanfaatan Peltier dan Heater Sebagai Alat Pengontrol Suhu Air Pada Bak Penetasan Telur Ikan Gurame. Conference on Information Technology, 295-299.

Saputra, V. H., Darwis, D., \& Febrianto, E. (2020). Rancang Bangun Aplikasi Game Matematika Untuk Penyandang Tunagrahita Berbasis Mobile. Jurnal Komputer Dan Informatika, 15(1), 1-8.

Saputra, V. H., Pasha, D., \& Afriska, Y. (2020). Design of English Learning Application for Children Early Childhood. 3(April), 661-665.

Sulistiani, H., Darwis, D., Silaen, D. S. M., \& Marlyna, D. (2020). Pengembangan Media Pembelajaran Akuntansi Berbasis Multimedia ( Studi Kasus : Sma Bina Mulya Gading. 15(1), 127-136.

Ulfa, M., \& Saputra, H. (2019). Pengaruh Media Pembelajaran Makromedia Flash dengan Pendekatan Matematika Realistik pada Hasil Belajar Siswa The Effect of Macromedia Flash Learning Media With Realistic Mathematics Approach to Student Learning Outcomes To cite this article : Pengaruh Med. Triple S, 2(1), 1221. 